This is an electronic reprint of the original article. This reprint may differ from the original in pagination and typographic detail.

Author(s): Rautiainen, Katri-Helena; Jäppinen, Aija

Title: Visual Literacy From the Perspective of the VTS Method

Year: $\quad 2017$

Version:

Please cite the original version:

Rautiainen, K.-H., \& Jäppinen, A. (2017). Visual Literacy From the Perspective of the VTS Method. Journal of Literature and Art Studies, 7(8), 1071-1082. https://doi.org/10.17265/2159-5836/2017.08.016

All material supplied via JYX is protected by copyright and other intellectual property rights, and duplication or sale of all or part of any of the repository collections is not permitted, except that material may be duplicated by you for your research use or educational purposes in electronic or print form. You must obtain permission for any other use. Electronic or print copies may not be offered, whether for sale or otherwise to anyone who is not an authorised user. 


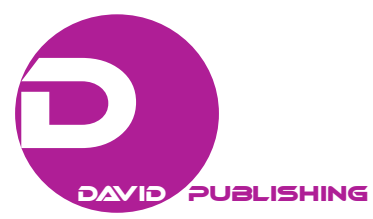

\title{
Visual Literacy From the Perspective of the VTS Method
}

\author{
Katri-Helena Rautiainen, Aija Jäppinen \\ University of Jyväskylä, Jyväskylä, Finland
}

\begin{abstract}
The purpose of this article is to investigate visual literacy from the perspective of the VTS (Visual Thinking Strategies) method. The authors examine the viewpoints of seven American elementary school teachers on visual literacy and its meanings in the context of the VTS method. Data collection was done using a semi-structured questionnaire, which was followed by theory-driven content analysis. The authors emphasize that when supporting holistic development in a teaching context, it is the interconnected nature of aesthetics, growth and the learner's learning which is more important than developing special skills, like visual literacy. In the teaching context visual literacy and language development should be acknowledged in pedagogy and research.
\end{abstract}

Keywords: visual literacy, visual thinking strategies, taxonomy for learning, aesthetics, multimodality

\section{Introduction}

The new Finnish basic education core curriculum (Opetushallitus, 2014) identifies multi-literacy as one of the goals of cross-curricular transversal competence. The visuality of literacy is classified as one component of multi-literacy. It is defined as "the skill of interpreting, producing and assessing different messages as well as the ability to obtain, adapt, produce, present and evaluate information in different learning environments and situations”. In considering the significance of multi-literacy it is relevant in this context to examine the PISA (Program for International Student Assessment) research study, which measures literacy internationally. According to PISA, Finnish young people's literacy scores are clearly poorer than they were in the early 2000s. The 2012 PISA study showed that the number of weaker readers especially has grown (Kupari, Välijärvi, Andersson, Arffman, Nissinen, Puhakka, \& Vettenranta, 2013). On the other hand, literacy nowadays can be understood in a broader context than those areas measured by tests. This being so, it is possible that measurements do not include those areas of literacy that are presently being used to an ever increasing extent. One example of this is the worldwide attention directed at the rise of digital information and its increasing importance in all fields (see also European Commission 2010). The transversal competence of people in developed countries includes information and communication technology skills and the literacy associated with them. As technology develops, this field is also constantly changing, resulting in new literacies that are complex and multimodal in nature (Coiro, Knobel, Lankshear, \& Leu, 2008, pp. 14-15).

Guided by this transversal competence goal of multi-literacy, we set out in search of a new methodological approach to train visual literacy. Our research topic further restricted itself to dealing with the VTS (Visual Thinking Strategies) or pictorial analysis method, developed by the American psychologist Abigail House

Katri-Helena Rautiainen, degree, academic title, Faculty of Education and Psychology, Department of Teacher Education, University of Jyväskylä, Finland.

Aija Jäppinen, degree, academic title, Faculty of Education and Psychology, Department of Teacher Education, University of Jyväskylä, Finland. 
(2001-2002) and Philip Yenawine, director of museum education (1997, 1999, 2011, 2013). The VTS method, which has been developed for over twenty years on the basis of research, nowadays functions as a teaching and learning method in many American schools and museums. Only recently has the method reached Finland where its use is mostly limited to museum pedagogy and experiments carried out by some individual teachers.

The purpose of this article is to clarify how US teachers employing the VTS method view visual literacy and the meanings they attach to it. First, we shall examine how class teachers using the VTS method define visual literacy and then identify what the instructor's and learner's visual literacy includes. The topic will also be considered from the perspective of image selection and assessment. Finally, the research task will be extended by asking what meanings are attached to visual literacy and visuality.

Since the roots of the VTS method lie in the United States, it was quite natural that we should restrict our research data collection to American class teachers employing the VTS method. We wished to select respondents as so-called VTS experts, who made regular use of this visual literacy method in their school teaching. Philip Yenawine, who developed the VTS method, helped in finding suitable research subjects by passing on contact information for 20 class teachers. Of these, seven took part in the actual data collection. Thus, subject selection used importance sampling, with the group being carefully chosen according to certain criteria (Eskola \& Suoranta 2014, p. 15; Tuomi \& Sarajärvi 2013, pp. 85-86).

Data were collected by means of a web-based questionnaire, which was constructed using Google Form. In addition to a basic information section, the questionnaire had two main parts: VTS in use and visual literacy. Space was left free for respondents to add comments, ideas, etc. The web-based questionnaire itself belongs to the category of survey research strategies (Hirsjärvi, Remes, \& Sajavaara, 2009, p. 134), but in carrying out our own study we adopted a qualitative approach. The questionnaire consisted of open-ended questions to which the subjects could freely respond. One starting point of qualitative research is that social reality is seen as adaptive and reflective. In this way the existence of social reality is effected through the meanings assigned to it by individuals (Flick, von Kardorff, \& Steinke, 2004, p. 7). In other words, the goal of qualitative research is precisely to seek to understand what is being investigated (see for example Eskola \& Suoranta, 2014, p. 13; Hirsjärvi et al., 2014, p. 164; Patton, 2002, p. 4; Tuomi \& Sarajärvi, 2013). Since the data do not contain interpretations, they require analysis (Patton, 2002, p. 27).

According to Krippendorf (2013), content analysis proceeds using an investigative approach. The aim is to open up the area related to how society functions and understands itself (Kippendorff, 2013, pp. 1-2). In line with the previously defined research task, in the present study the examination restricts itself to visual literacy. Schreier (2012) considers defining the research problems to be a significant factor in carrying out content analysis and selecting a viewpoint, as well as in implementing the analysis process itself.

We adopted a theory-led approach in analysing the web questionnaire forms. This form of analysis employs abductive reasoning, which involves inductive or data-oriented, and deductive or theory-led reasoning (Tuomi \& Sarajärvi, 2013, p. 97). This theory-led content analysis proceeds in accordance with the analysis process presented by Tuomi and Sarajärvi (2013). We begin by picking out the original expressions from the data, for which we then create simplified expressions (reduction). After this the analysis proceeds from the formation of subcategories (grouping) to the constitution of higher categories (clustering). At the data abstraction stage the data are added to the theories. Here earlier theories are compared with each other and with the categories derived from the data. The data analysis process is depicted using tables. Any factors/results 
emerging from these are then compared with research studies carried out in aesthetic development, taxonomy of learning and visual literacy.

\section{The VTS Method and Visual Literacy}

The initial purpose of the VTS method was to develop aesthetic understanding by means of looking at art (Housen, 2001-2002, pp. 99-100). In addition, the method can be used to also develop the learner's visual literacy, thinking and interactional skills, such as listening and self-expression (Yenawine, 2013, p. 19). The VTS method is based on Rudolf Arnheim's theory and Abigail Housen's stage theory of aesthetic development. It has also been influenced by the developmental theories of Piaget, Vygotsky, Dewey and Bruner (VUE staff n.d.b; Yenawine, 1999). Underlying the elaboration of the method are Housen's five thinking stages of aesthetic development (see Figure 1) (De Santis \& Housen, 1996; Housen, 2001-2002).

Development of the VTS method has led to a sequential three-year teaching programme (see Figure 1) distributed across grades 1-5 (Kindergarten—Grade 5) (VUE staff n.d.a.). For this article we have condensed these teaching levels (see Figure 1). The programme is designed to make it possible to begin at any stage of lower school. At the first stage the learner examines and identifies art and develops various skills such as thinking, language, listening and discussing as well as creating a personal relationship to art. At the second level these objectives are further extended. The learner understands that many artworks tell stories, the possible meanings of which s/he assesses by sharing opinions. Thinking skills are developed by answering structured questions. In addition, communicative skills are reinforced and further extended to include written exercises on a computer and respecting others' viewpoints. At the third level, in addition to the previous objectives, an effort is made to further develop the learner's self-assurance with him/her seeking specific information on a topic. A shift is now made from group discussions to small groups, where the learner has to rely more on his/her own views and skills. An additional objective is to transfer experiences of the VTS method to other subjects. Even though these objectives are grouped at various levels, the VUE organization's instructions are that the objective for every year group is to develop the learner's self-assurance, involvement, visual literacy and thinking by applying the skill of questioning, modifying viewpoints and reflecting. It is also recommended that the skill is applied and extended outside school from the first level onwards (VUE staff n.d.a.).

According to Yernawine (1999), the VTS method was originally developed to implement the first two stages of Housen's aesthetic development. For Housen (2001-2002), at the first accountive stage the viewer is a storyteller who uses, for example, memories in making interpretations (see Figure 1). At the constructive stage the viewer constructs a frame of reference for his/her own observations, knowledge and value systems. In this way the viewer is already forming criteria for a realistic assessment. When we examine the third classifying stage, where the viewer is already applying an analytical and critical viewpoint as well as wishing to assign an artwork to its historical context, it is possible to see points of overlap with the third stage of the VTS method. Housen's fourth interpretive stage can also be partly included among the stages of the VTS method. Housen's critical thinking skill is practised in the VTS method, for example, by questioning and forming one's own viewpoint. The outcome of this comparision appears to be that Housen's stages of aesthetic development are implemented in the VTS method to a greater degree than was originally planned. 


\begin{tabular}{|r|c|c|}
\hline Aesthetic Development & Taxonomy of Learning & Visual Literacy \\
\hline
\end{tabular}

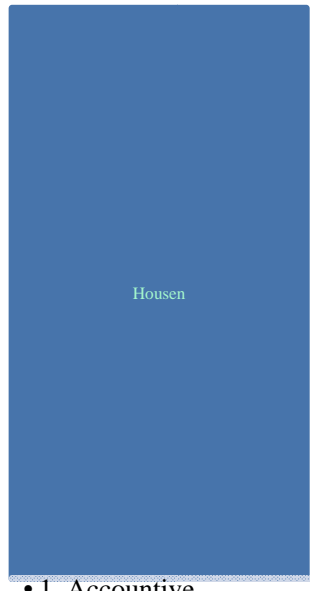

-1. Accountive

-2. Constructive

-3. Classifying

-4. Interpretive

-5. Recreative

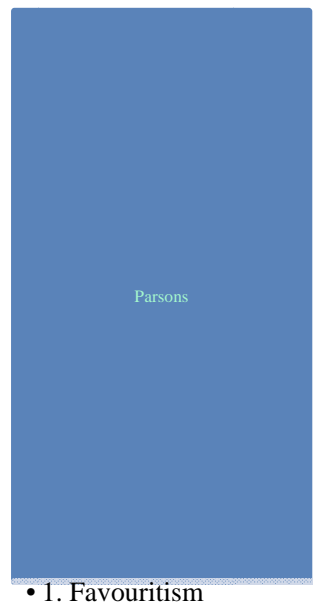

-2. Beauty and realism

-3. Expressiveness

• 4. Style and form

• 5. Autonomy

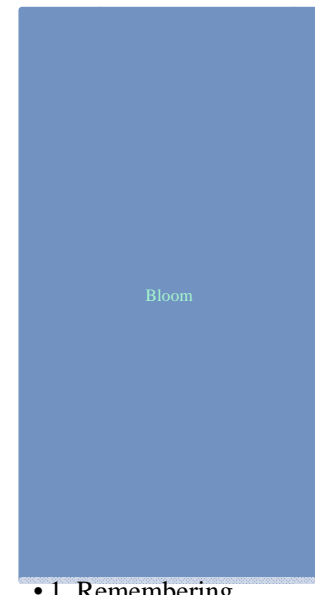

-1. Remembering

• 2. Understanding

•3. Applying

-4. Analyzing

-5. Evaluating

-6. Creating

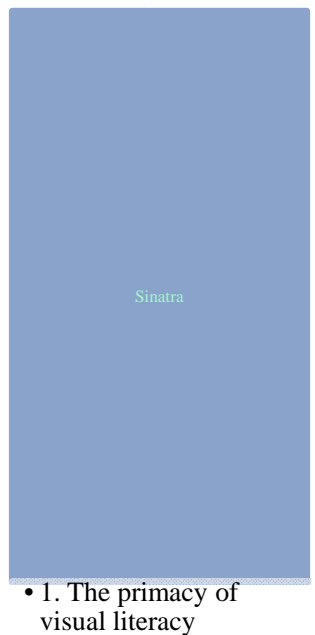

1. Examine, identify, de velop thinking, language and listening skills, share associations (grade 1)

-2. Understand, extend skills into writing, evaluate meanings (grades 2-3)

•2. Oral literacy

• 3. Written literacy

-4. Visual literacy: representational communication
-3. Transfer to other subjects, seek, to rely on themselves (grades 4-5)

Figure 1. Comparison of VTS method stages with Housen's and Parsons' aesthetic development, Bloom's taxonomies of learning, and Sinatra's visual literacy.

In addition to comparing the VTS method and Housen's aesthetic development, we also examined them in respect of Parsons' (1976; 1987; 1989; 1990) five-stage theory of aesthetic development, of Sinatra's (1986, pp. 28-29) four-phase development of visual literacy, and of Bloom's (Anderson, Krathwohl, \& Pintrich, 2001, pp. 28-34; cf. Bloom (Ed.) 1959, p. 18) taxonomies. One result of comparing these theories is to discover overlaps between them (see Figure 1). On the basis of these theories it is possible to construct a common synthesis for the development of visual literacy. In this model, development commences with identifying and cataloguing where the viewer investigates, remembers and describes his/her observations, as well as both describing his/her own preferences and using his/her senses and associations in making an interpretation. The next step is that the viewer understands, develops and extends various skills (e.g. from discussing to writing), as well as considering the meaning of images and the expressivenness of an artwork. From here the process moves on to application, where the viewer is able to discover points of contact in his/her own vicinity and can link what he/she sees to a wider historical context. This also involves classifying. The fourth element to arise is analysis and evaluation, in which the examination is interpretive and classifying, and includes the goal of discovering 
the deepest meanings of an artwork on the basis of critical thinking. The last stage is that of autonomy and re-creating. The features mentioned above figure in each researcher's definitions. They are merely grouped or relate to each other differently. One distinguishing feature is the way the VTS method progresses in the development of the skills acquired through visual literacy, with VUE defining them in a form adapted for children. In this way the stages of development lead to higher levels, but the depth of treatment and the rate of progress at each stage is more restricted than for someone whose visual literacy has required considerable time and practice.

\section{Results and Interpretation}

The data from our research population yielded four simplified expressions which were used to conceptualize visual literacy (synthesis) (see Table 1). Visual literacy was conceptualized to include discussing an image in words, in one's thoughts (i.e. without words), which took place largely through interactive representations led by the teacher or discussion facilitator (facilitation) between the individual and/or group. An important part of discussing images included the ability to understand the meaning of the images. Support was also given by providing a point of departure for the images. The view was that the ability to write about images was also an inseparable part of visual literacy. As with the authors above, the aim of this was to promote interactive and self-expressive skills (higher category). A comparison of these results with Sinatra's (1986) presentation of visual literacy development reveals many points of overlap (see Figure 1). Sinatra emphasises that literacies interact with each other, despite their phasic nature. This can also be seen in the teachers' definitions. The idea of aesthetic engagement raised by Sinatra, however, does not emerge from our data. Furthermore, Housen's (2001-2002) and Parsons' (1987; 1989; 1990) stages of aesthetic development and Bloom's (Anderson, Krathwohl, \& Pintrich, 2001, pp. 28-34) taxonomies of learning were not recognised in our data, either. It therefore appears that for those using the VTS method in school, aesthetic considerations in the process of developing visual literacy are not of central importance and that attention is directed to interactive and self-expressive skills.

Table 1

Conceptualisation of Visual Literacy.

\begin{tabular}{|c|c|c|c|c|}
\hline Original expressions & Simplified expression & Sub-category & Higher category & Synthesis \\
\hline $\begin{array}{l}\text { The ability to construct meaning presented } \\
\text { in a visual image and to discuss this content } \\
\text { with others. }\end{array}$ & $\begin{array}{l}\text { Ability to understand the } \\
\text { meanings of images and } \\
\text { talk about them. }\end{array}$ & $\begin{array}{l}\text { Talking about an image } \\
\&\end{array}$ & & \\
\hline $\begin{array}{l}\text { When someone has the capacity to look at } \\
\text { an image and attempt to make sense of it, } \\
\text { either with spoken works or internal } \\
\text { thoughts. }\end{array}$ & $\begin{array}{l}\text { Ability to understand an } \\
\text { image in words or } \\
\text { thoughts. }\end{array}$ & $\begin{array}{l}\text { Thinking about an } \\
\text { image }\end{array}$ & $\begin{array}{l}\text { Interactive and } \\
\text { self-expressive } \\
\text { skill }\end{array}$ & \\
\hline $\begin{array}{l}\text {-developing skills to read, speak about, and } \\
\text { write a visual scene or representation: } \\
\text {-Tier } 2 \text { vocabulary, clear communication, } \\
\text { ability to reflect critically on the underlying } \\
\text { meaning of a visual feature, setting one's } \\
\text { imagination free-. }\end{array}$ & $\begin{array}{l}\text { Ability to express a } \\
\text { visual image or } \\
\text { representation. }\end{array}$ & $\begin{array}{l}\text { Writing about an image } \\
\text { and communication }\end{array}$ & & $\begin{array}{l}\text { Visual } \\
\text { literacy }\end{array}$ \\
\hline $\begin{array}{l}\text { Visual literacy is using images to develop a } \\
\text { shared understanding or facilitate a } \\
\text { discussion about a topic. }\end{array}$ & $\begin{array}{l}\text { Using images to support } \\
\text { understanding or } \\
\text { conversation. }\end{array}$ & $\begin{array}{l}\text { (Understanding from } \\
\text { an image) } \\
\text { Supporting discussion }\end{array}$ & & \\
\hline
\end{tabular}

Significant factors forming part of the facilitator's visual literacy are the teacher's own guidance 
(pedagogic) skills, i.e. facilitative skills, and his/her skills in interpreting images, as well as motivating students to apply their visual literacy (see Table 2). The higher categories here include image interpretation and encouraging application of visual literacy to thematic areas other than the visual image. These factors associated with facilitators' skills emerging from the data did not deal with aspects of aesthetic development. In contrast, the goal was to attain levels of analysis and assessment in the facilitator's own image interpretation skills, levels which are also practised in Bloom's taxonomies of learning (Anderson, Krathwohl, \& Pintrich, 2001, pp. 28-34). Facilitative skills and generally encouraging students to apply their skills more widely emerged solely in the stated goals of the VTS method (cf. Figure 1). On the other hand, this can be understood to mean that the interpretative, autonomous and re-creative level included applying the skill in new situations and contexts, the possible result of which is also re-creation. It is in this direction that facilitators at least want to encourage their students.

In addition to our data, other studies also reveal the importance of the teachers' own visual literacy and understanding. They highlight the importance of the teachers' own ability to use and understand precise meta-language in different socio cultural contexts. When this is mastered, the teacher is able to teach and facilitate visual literacy (Kern, 2000; Serafini, 2010; 2011; 2015; Unsworth, 2006.) The development of the VTS method itself, however, has taken as its starting point that no previous knowledge of art is required of the teacher. The teacher is not in the role of an expert, but rather s/he functions as a facilitator or supervisor (Yenawine, 1998). In contrast the teachers in our data assigned an important role to the teacher's own visual literacy.

Table 2

Forming Views on the Facilitator's Visual Literacy.

\begin{tabular}{|c|c|c|c|c|}
\hline Original expressions & Simplified expression & Sub-category & Higher category & Synthesis \\
\hline $\begin{array}{l}\text { - Listening closely, validating by } \\
\text { paraphrasing, staying neutral in my } \\
\text { comments and facial expressions when } \\
\text { receiving student contributions, making } \\
\text { connections, framing their thoughts. }\end{array}$ & $\begin{array}{l}\text { Encouraging students to } \\
\text { constantly observe and } \\
\text { describe the environment }\end{array}$ & $\begin{array}{l}\text { Encouraging } \\
\text { extensive use of the } \\
\text { skill }\end{array}$ & $\begin{array}{l}\text { Encouraging skill } \\
\text { application }\end{array}$ & \\
\hline $\begin{array}{l}\text { I often think about my deficiencies in } \\
\text { visual literacy or my former deficiencies. } \\
\text { They help me to understand how honing } \\
\text { my facilitation skills might help students } \\
\text { overcome these same deficiencies. }\end{array}$ & Facilitation skills & $\begin{array}{l}\text { Supervising skills } \\
\text { for image } \\
\text { interpretation }\end{array}$ & $\begin{array}{l}\text { Image } \\
\text { interpretation }\end{array}$ & $\begin{array}{l}\text { Visual literacy of } \\
\text { facilitator/teacher }\end{array}$ \\
\hline $\begin{array}{l}\text { I constantly teach that learning is a } \\
\text { reflective process—-, there can be many } \\
\text { ways to solve a problem-. }\end{array}$ & $\begin{array}{l}\text { Thinking of learning as a } \\
\text { reflective process and } \\
\text { problem-solving }\end{array}$ & & & \\
\hline $\begin{array}{l}\text { I spend time looking at the images myself } \\
\text { before I show them to the kids. }\end{array}$ & $\begin{array}{l}\text { Carrying out one's own } \\
\text { pictorial analysis }\end{array}$ & $\begin{array}{l}\text { Image interpretation } \\
\text { skill of } \\
\text { facilitator/teacher }\end{array}$ & & \\
\hline
\end{tabular}

The responses of teachers using the VTS method revealed five factors (sub-categories) which developed in students using the pictorial analysis method. While examing an image and talking about it, students develop their skills in verbal expression, listening and critical thinking, as well as in reflection and communication (see Table 3). These were assigned to the higher category of "investigate and interpret". The fourth sub-category to emerge from the data was the general transfer of the above skills for the child's everyday use. In addition to this transfer effect, those using the method also considered reinforcement of the child's self-assurance to be significant. These last two sub-categories diverge from the definitions of actual visual literacy, aesthetic 
development and taxonomies of learning (higher category: application). The skill of application was also included as part of the teacher's visual literacy (cf. Table 2). The factors constituting students' visual literacy also emerge from Sinatra's (1986) stages of development where visual literacy is developed by looking, listening, speaking and writing, as well as by communicating. In the same way as with the teachers' skills (see Table 2), the ability to extend application to other areas was also consistently included among the students' skills. In this way, then, in accordance with the previous table, we can see points of overlap with Housen, Parsons and Bloom.

Table 3

Forming Views of the Learner's Visual Literacy.

\begin{tabular}{|c|c|c|c|c|}
\hline Original expression & Simplified expression & Sub-category & Higher category & Synthesis \\
\hline $\begin{array}{l}\text { - Conditional language, etc. Gave her a } \\
\text { unique space and opportunity to practice all } \\
\text { these skills-. } \\
\text {-They listen to each other more carefully. }\end{array}$ & $\begin{array}{l}\text { Developing conditional } \\
\text { language and listening to } \\
\text { others }\end{array}$ & $\begin{array}{l}\text { Linguistic competence } \\
\text { and listening } \\
\text { competence }\end{array}$ & & \\
\hline $\begin{array}{l}\text {-Oral expression of simple ideas, whether } \\
\text { description, detailed description, inferences, } \\
\text { supported inferences, }\end{array}$ & $\begin{array}{l}\text { From naming to making } \\
\text { inferences about an image }\end{array}$ & & $\begin{array}{l}\text { Investigate and } \\
\text { interpret }\end{array}$ & \\
\hline $\begin{array}{l}\text {-The way the students discuss an image } \\
\text { becomes more complex and verbose as the } \\
\text { year unfolds. }\end{array}$ & $\begin{array}{l}\text { Ability to understand } \\
\text { more complex material } \\
\text { over time }\end{array}$ & $\begin{array}{l}\text { Skill of critical, } \\
\text { thinking, reflection } \\
\text { and communication }\end{array}$ & & $\begin{array}{l}\text { Learner's } \\
\text { visual } \\
\text { literacy }\end{array}$ \\
\hline $\begin{array}{l}\text {-They are sharing their interpretation of } \\
\text { the narrative and whether or not their } \\
\text { interpretation is in agreement or } \\
\text { disagreement with the other students that } \\
\text { have gone before them. }\end{array}$ & $\begin{array}{l}\text { Presenting supported } \\
\text { views and comparing } \\
\text { them and arguing them } \\
\text { with others }\end{array}$ & & & \\
\hline $\begin{array}{l}\text {-Apply the skills readily to other areas. } \\
\text { They use complete sentences when they talk } \\
\text { to each other during classroom } \\
\text { conversations. }\end{array}$ & $\begin{array}{l}\text { Applying skills to other } \\
\text { areas: observing, } \\
\text { development, of } \\
\text { languaging }\end{array}$ & Transfer effect & $\begin{array}{l}\text { Applying to other } \\
\text { areas (separate } \\
\text { from definition } \\
\text { of visual literacy) }\end{array}$ & \\
\hline $\begin{array}{l}\text {-I see so much confidence in my students } \\
\text { as they have mastered the process. I believe } \\
\text { the confidence extends beyond visual } \\
\text { literacy. }\end{array}$ & $\begin{array}{l}\text { Self-esteem to take part in } \\
\text { discussion (not a } \\
\text { definition of visual } \\
\text { literacy) }\end{array}$ & Self-confidence & & \\
\hline
\end{tabular}

The assessment of visual literacy was directed at the same areas that were included in the learner's visual literacy (cf. Tables 3 and 4). Teachers focussed their assessment on the learner's linguistic ability and writing (higher category "investigate and interpret”), which were revealed, for example, in a greater number of words and in being able to write about an image. The third area to appear in assessment was applying these skills to other areas, i.e. skill transfer. The teachers' assessment activities were thus consistent with what they expected and designated as belonging to visual literacy. These objects of assessment also appear in Housen and Yenawine's (n.d.a.) assessment descriptions. In addition, however, Yenawine (2013) uses six areas to categorize the assessment of how thinking develops. These are: observations, inferences, evidence, speculation, 
elaboration and revision. In addition, VTS distributes assessment material to teachers for their own use. This material focuses on overall assessment of vocabulary, overall assessment of linguistic competence, overall assessment of clarity and VTS-related thinking behaviors. According to Callow (2005; 2008), assessing visual literacy includes evaluating texts and discussion where the focus is on personal experience and aesthetic interpretation, use of meta-language and socio-critical understanding. Tillman (2012), again, makes use of Bloom's taxonomies in assessing visual literacy (cf. Figure 1). Correspondingly, in assessing literacy Linnakylä (1990) emphasizes the learning process and strategies for learning from the text, which means that here too the student's progress from one level to another is not being assessed. This concern with the primacy of the learning process is also visible in the data. Teachers are interested rather in the development taking place during the learning process and its transfer for the learner's wider use than in the achievement of individual objectives. Thus, assessment of investigation and interpretation as well as of application is carried out in a wider context than merely during use of the VTS method.

Table 4

Forming Views of Assessing Visual Literacy.

\begin{tabular}{|l|l|l|l|l|}
\hline Original expressions & Original expressions & Sub-category & Higher category & Synthesis \\
\hline $\begin{array}{l}\text {-Number of spoken words and the kinds } \\
\text { of ideas they are sharing. }\end{array}$ & Increased number of words & Linguistic competence & & \\
\hline $\begin{array}{l}\text {-An image in a text and making solid } \\
\text { connections to the text. They are able to } \\
\text { back up their inferences with evidence } \\
\text { unprompted. }\end{array}$ & Connecting image and text & Comparison & $\begin{array}{l}\text { Investigate } \\
\text { interpret }\end{array}$ & and \\
$\begin{array}{l}\text { They were able to apply it to other } \\
\text { subject areas-. }\end{array}$ & Applying to other areas & Transfer effect & Applying & \\
\hline
\end{tabular}

In the data student-centredness and the learner's interpretation emerged as criteria for selecting visual literacy images (higher categories) (see Table 5). Teachers considered it important that the learners can themselves choose the picture to be discussed. According to teachers, further criteria for a good visual image were that the picture arouses discussion, even argument, amongst students and that it can be used naturally to tell a story. In contrast, Yenawine (2003; 2011) considers that first and foremost it is good to use thoughtfully selected images. Yenawine's approach to selecting images, then, differs from the student-centred principle adopted by teachers. What Yenawine and the teachers have in common is that selecting an image must take into account its interest level, familiarity, multiplicity of interpretation, and narrativity.

In a more general examination of image selection criteria, the discussion reveals a diverse range of possibilities related to image selection. According to some researchers, postmodern picture books can also be used in the teaching of visual literacy. Teaching then directs attention to the use of, for example, framing, lines and colours in the picture book as well as the different proportions of the text (see for example O'Neil, 2011; Serafini, 2010; 2011; 2012; Serafini \& Gee, 2014; Stafford, 2011; Unsworth, 2006). In addition to picture books, teaching can also make use of graphic novels (Wolfen \& Kleijwegtin, 2012). Even works of non-fiction can be employed in teaching visual literacy (Smolkin \& Donovan, 2005). The concept of "image/text” and "mixed media" is used to describe this type of blending together of image and text (Mitchell, 1994). Nowadays the term multimodal is applied to texts which make use not only of image and text but also, for example, of graphic elements, hypertexts, links and the moving image. In addition to visual and verbal, we can also talk 
about auditive, kinetic and numerical forms of representation, which are called modes or modalities (See for example Cope \& Kalantzis, 2000; Kress, 2003; 2010; Kress \& Leeuwen, 2006; New London Group, 1996; Räsänen, 2015; Serafini, 2010; 2011; 2012; 2015; Unsworth, 2001; 2006). It would thus seem that visual material deriving from particularly diverse starting points is suitable for training visual literacy.

Table 5

Forming Views of Image Selection Criteria for Visual Literacy.

\begin{tabular}{|l|l|l|l|l|}
\hline Original expression & Simplified expression & Sub-category & Highert category & Synthesis \\
\hline $\begin{array}{l}\text { I let them investigate the scene and point } \\
\text { out what most inspired/intrigued them. }\end{array}$ & Students choose the image & Student & Learner-centredness & \\
\hline I shoot for images that are debatable. & Image arouses discussion & Debatability & Learner's & Choice of image \\
\hline $\begin{array}{l}\text { I will look for images that suggest some } \\
\text { sort of narrative. }\end{array}$ & $\begin{array}{l}\text { Story can be created from } \\
\text { image }\end{array}$ & Narrativity & interpretation & \\
\hline
\end{tabular}

In examing the meanings assigned to visual literacy and visuality by class teachers who have used the VTS method, we discover the same emphasis given to transferring the skill to other areas as was seen above in the formation of views regarding the facilitator, the learner and assessment (cf. Tables 2-4, 6). In addition, the value attached to visual literacy includes developing the learner's self-esteem, the faciltator's professional development and its beneficial effect on teaching. These above-mentioned sub-categories count among the secondary meanings in using the method (higher category). In other words, secondary meaning here means that greater weight is attached to these meanings than to the meaning of developing visual literacy itself.

The instrumental values of visual literacy also included expressions partially falling into the benefit category. These were the significance of visual literacy in supporting the learner's writing and discussion, along with the weight given by the teacher to the curriculum and the subject being taught. At the same time, these continue to count among secondary meanings.

Sustained examination of an image, its discussion, as well as its enjoyment can count as an intrinsic value of visual literacy. This can also be seen here as a matter of the VTS method pursuing an aesthetic experience goal, even though the word aesthetics did not feature directly in the data. This being the case, only these sub-categories count among primary meanings. The method of categorizing meaning presented by Moilanen and Räihä (2015, p. 54) has been used in classifying visual literacy and visual meaning assignment. They use the levels of individual, community and universal community consciously and unconsciously. Jäppinen (2016, p. 74), again, applies Moilanen and Räihä's (2015) meaning assignment to an examination of the impact of visual literacy and the instrumental and intrinsic value of visuality. In this article Jäppinen's classification has been further developed to exclude conscious and unconscious classification. The sub-categories emerging as a result of the data analysis results reshaped the categorization.

Table 6

Meanings of Visual Literacy and Visuality.

\begin{tabular}{|l|l|l|l|l|}
\hline Original expressions & Simplified expression & Sub-category & Higher category & Combined \\
\hline $\begin{array}{l}\text { As the year progresses I see so much } \\
\text { confidence in my students as they have } \\
\text { mastered the process. I believe the } \\
\begin{array}{l}\text { confidence extends beyond visual } \\
\text { literacy. }\end{array}\end{array}$ & $\begin{array}{l}\text { Developing self-esteem is } \\
\text { more important than } \\
\text { developing visual literacy }\end{array}$ & $\begin{array}{l}\text { Developing } \\
\text { self-esteem }\end{array}$ & $\begin{array}{l}\text { Importance of } \\
\text { visual literacy }\end{array}$ \\
\hline $\begin{array}{l}\text { Linking ideas, rephrasing with other } \\
\text { vocabulary, and categorizing have all } \\
\text { helped students arrive at a higher level. }\end{array}$ & $\begin{array}{l}\text { Method helps student } \\
\text { improve and develop in } \\
\text { many areas. }\end{array}$ & $\begin{array}{l}\text { Transferring skill } \\
\text { to other areas }\end{array}$ & $\begin{array}{l}\text { Secondary meaning is } \\
\text { assigned to visuality in } \\
\text { using the method }\end{array}$ & \\
\hline
\end{tabular}




\begin{tabular}{|c|c|c|c|c|}
\hline $\begin{array}{l}\text {-Since it was one of the best } \\
\text { professional development workshops } \\
\text { that were offered. }\end{array}$ & $\begin{array}{l}\text { Use of the VTS method } \\
\text { has promoted the teacher's } \\
\text { professional development. }\end{array}$ & $\begin{array}{l}\text { Professional } \\
\text { development }\end{array}$ & & \\
\hline $\begin{array}{l}\text { Visual literacy is using images to } \\
\text { develop a shared understanding or } \\
\text { facilitate a discussion about a topic. }\end{array}$ & $\begin{array}{l}\text { Visual literacy is } \\
\text { meaningful in supporting } \\
\text { writing and discussion } \\
\text { skills as well as benefiting } \\
\text { teaching. }\end{array}$ & Benefit value & & $\begin{array}{l}\text { Instrumental } \\
\text { value of visual } \\
\text { literacy }\end{array}$ \\
\hline $\begin{array}{l}\text { I tried to align it with the Common Core } \\
\text { Learning Standards, and the topics that } \\
\text { we covered in Math and Science classes } \\
\text {-. }\end{array}$ & $\begin{array}{l}\text { The curriculum and } \\
\text { subject being taught are } \\
\text { more important than } \\
\text { visuality. }\end{array}$ & & & \\
\hline $\begin{array}{l}\text { Given the speed with which students are } \\
\text { supposed to process visual information } \\
\text { when using digital technology, they need } \\
\text { the balance that VTS provides.- } \\
\text { opportunities to look long and reflect } \\
\text { deeply_-. }\end{array}$ & $\begin{array}{l}\text { Unlike the deluge of } \\
\text { images of technology, the } \\
\text { VTS method offers the } \\
\text { possibility of examining } \\
\text { and discussing an image in } \\
\text { peace }\end{array}$ & Motionless image & $\begin{array}{l}\text { Primary meaning } \\
\text { assignment }\end{array}$ & $\begin{array}{l}\text { Intrinsic value } \\
\text { of visual } \\
\text { literacy }\end{array}$ \\
\hline $\begin{array}{l}\text { It's one of my favourite moments in the } \\
\text { school day/week, and the students } \\
\text { absolutely love it as well. }\end{array}$ & $\begin{array}{l}\text { Teacher and students enjoy } \\
\text { looking at an image and } \\
\text { discussing it. }\end{array}$ & Enjoy the image & & \\
\hline
\end{tabular}

\section{Conclusion}

The purpose of this article was to shed light on the views of teachers using the VTS method and the meanings they attach to visual literacy. The study reveals that a central element of the definition of visual literacy is interactional and self-expression skills, which were practised by means of image discussion, writing, representations, comprehension and thinking skills. The facilitator's visual literacy included the facilitator's own image interpretation and ability to guide image interpretation as well as encouraging the student to make extensive use of his/her skill. In accordance with the definition of visual literacy, the student's visual literacy embraced those areas associated with communicative skill, command of spoken and written language as well as listening and critical thinking skills. In addition, emphasis was given to bolstering self-assurance and transferring the skills acquired with the VTS method to other school subjects. Apart from self-assurance, these same areas were stressed in the learners' assessment. The criterion for image selection was student-centredness with the students being allowed to select the image they want. Additionally, the image should arouse discussion and a story can be told about it. In using the method, secondary meanings were given to visual literacy and visuality, which included developing self-esteem, skill transfer, professional development and benefit. In contrast, the primary meaning of visual literacy emerged in examining a still image and the pleasure deriving from this.

In the light of these results, we notice that teachers uniformly stress that, with the help of the VTS method, communicative, self-expressive, thinking and application skills have further developed. Aesthetic experience and the associated visual literacy, which is one of the most important principles of the VTS method, remain in the background. On the other hand, asking the VTS discussion questions (1. What's going on in this picture? 2. What do you see that makes you say that? 3. What more can we find?), is an attempt to shape permanent cognitive strategies which ultimately can be applied beyond looking at art (Yenawine, 2013). It would thus appear that use of the VTS method also has wider meanings in the child's overall development. In order for the benefits deriving from using this method to be actualized, users of the method should have good visual literacy and a good understanding of this literacy, or at least that it would be of use (cf. also Kern, 2000, pp. 316-317; 
Serafini, 2010; 2011; 2015; Unsworth, 2006).

From a Finnish perspective, one of the goals of the basic education core curriculum (Opetushallitus, 2014) is the implementation of phenomenological learning. Central to phenomenon-based learning is the idea that phenomena are examined in authentic contexts and that the knowledge and competences related to the phenomena are practised across subject boundaries (Moilanen, 2016). From the viewpoint of developing the VTS method, it would be important for teacher education to be involved in developing this method. In this way, through extensive application and research into the method in different areas of learning and operational contexts, it would be possible to make better use of it and direct its development towards meeting future needs. In achieving these goals good use could be made of visual literacy as a phenomenon to be practised in various contexts. What is required are new pedagogical approaches and creative forms of competence to set the right course for the methodological and pedagogical development of teaching.

\section{References}

Anderson, L. W., Krathwohl, D. R., \& Pintrich, P. R. (2001). The taxonomy table. In L. W. Anderson, D. R. Krathwohl, P. W. Airasian, K. A. Cruikshank, R. E. Mayer, P. R. Pintrich, J. Raths \& M. C. Wittrock (Eds.) A taxonomy for learning, teaching, and assessing: A revision of Bloom's taxonomy of educational objectives (pp. 27-37). New York: Longman.

Engelhart, M. D., Furst, E. J., Hill, W. H., Krathwohl, D. R. (1959). Taxonomy of educational objectives. In B. S. Bloom, (Ed.), Handbook I: The cognitive domain (2nd ed). Torondo: Longmans.

Callow, J. (2005). Literacy and the visual: Broadening our vision. English Teaching: Practice and Critique, 4(1), 6-19.

Callow, J. (2008). Show me: Principles for assessing students’ visual literacy. The Reading Teacher, 61(8), 616-626.

Coiro, J., Knobel, M., Lankshear, C., \& Leu J, D. (2008). Central issues in new literacies and new literacies research. In J. Coiro, M. Knobel, C. Lank-shear, and D. Leu J. (Eds.), Handbook of research on new literacies (pp. 1-21). New York: Lawrence Erlbaum Associates, Taylor \& Francis Group.

Cope, B., \& Kalantzis, M. (2000). Introduction multiliteracies: The beginnings of an idea. In B. Cope and M. Kalantzis (Eds.), Multiliteracies: Literacy learning and the design of social futures (pp. 3-8). London: Routledge.

De Santis, K., \& Housen, A. (1996). A brief guide to developmental theory and aesthetic development. New York: Vtshome. Retrieved from http://www.vtshome.org/re- search/articles-other-readings.

Eskola, J., \& Suoranta, J. (2014). Introduction to the qualitative research (Johdatus laadulliseen tutkimukseen) (10th ed.). Tampere: Vastapaino.

Euroopan komissio. (2010). Communication from the Commission to the European Parliament, the Council, the European Economic and Social Committee and the Committee of the Regions. Communication from the Commission of the European Digital Agenda (Komission tiedonanto Euroopan parlamentille, neuvostolle, Euroopan talous- ja sosiaalikomitealle ja alueiden komitealle. Euroopan digitaalistrategia). Bryssel.

Flick, U., von Kardorff, E., \& Steinke, I. (Eds.) (2004). A companion to qualitative research. London: Sage.

Hirsjärvi, S., Remes, P., \& Sajavaara, P. (2009). Study and write (Tutki ja kirjoita) (15th ed.). Hämeenlinna: Tammi.

Hirsjärvi, S., Remes, P., \& Sajavaara, P. (2014). Study and write (Tutki ja kirjoita) (19th ed.). Helsinki: Kirjayhtymä.

Housen, A. (2001-2002). Aesthetic thought, critical thinking and transfer. Arts and Learning Research Journal, 18(1), 99-132. New York: Vtshome. Retrieved from http://www.vtshome.org/research/articles-other-readings

Housen, A., \& Yenawine, P. Assessing growth. New York: Vtshome. Retrieved data from http://www.vtshome.org/research/articles-other-readings

Jäppinen, A. (2016). VTS and visual literacy. The views of American users on visual literacy and its meanings in the context of VTS method (VTS ja visuaalinen lukutaito. Yhdysvaltalaisten käyttäjien näkemyksiä visuaalisesta lukutaidosta ja sen merkityksestä VTS -menetelmän osana). Kasvatustiede. Opettajankoulutuslaitos. Jyväskylän yliopisto.

Kern, R. (2000). Literacy and language teaching. Oxford: Oxford University Press.

Kress, G. (2003). Literacy in the new media age. London: Routledge.

Kress, G. (2010). Multimodality: A social semiotic approach to contemporary communication. London: Routledge.

Kress, G., \& Leeuwen, T. (2006). Reading images: The grammar of visual design (2nd ed.). London: Routledge.

Krippendorff, K. (2013). Content analysis: An introduction to its methodology. Los Angeles: Sage. 
Kupari, P., Välijärvi, J., Andersson, L., Arffman, I., Nissinen, K., Puhakka, E., \& Vettenranta, J. (2013). Pisa 12: Primary results (Pisa 12: Ensituloksia). Helsinki: Opetus- ja kulttuuriministeriö. Opetus- ja kulttuuriministeriön julkaisuja 2013: 20.

Linnakylä, P. (1990). Lukutaito—valmiutta ja vapautta (Literacy—Readiness and Freedom). In P. Linnakylä, and S. Takala (Eds.), New dimensions of reading (Lukutaidon uudet ulottuvuudet) (pp. 1-22). Kasvatustieteiden tutkimuslaitoksen julkaisusarja. Jyväskylä: Kasvatustieteiden tutkimuslaitos.

Mitchell, W. J. T. (1994). Picture theory: Essays on verbal and visual representation. Chicago (Ill.): University of Chicago Press. Moilanen, P., \& Räihä, P. (2015). Merkitysrakenteiden tulkinta (Interpretation of meaning structures). In R. Valli, and J. Aaltola (Eds.), Windows to research methods 2 (Ikkunoita tutkimusmetodeihin 2, näkökulmia aloittelevalle tutkijalle tutkimuksen teoreettisiin lähtökohtiin ja analyysimenetelmiin) (4th ed.) (pp. 52-73). Jyväskylä: PS-kustannus.

Moilanen, P. (2016). The temptations of a phenomenon-based approach. A department tallecture, 17.5.2016. University of Jyväskylä.

New London Group. (1996). A pedagogy of multiliteracies: Designing social futures, 66(1), 60-92.

O’Neil, K. E. (2011). Reading pictures: Developing visual literacy for greater comprehension (pp. 214-223). Reading Teacher, 65(3), 214-223.

Opetushallitus. (2014). National core curriculum for basic education 2014 (Perusopetuksen opetussuunnitelman perusteet 2014). Helsinki: Opetushallitus.

Parsons, M. J. (1976). A suggestion concerning the development of aesthetic experience in children. The Journal of Aesthetics and Art Criticism, 34(3), 305-314.

Parsons, M. J. (1987). Talk about a painting: A cognitive developmental analysis. Journal of Aesthetic Education, 21(1), 37-55.

Parsons, M. J. (1989). How we understand art: A cognitive developmental account of aesthetic experience. Cambridge: Cambridge University Press.

Parsons, M. J. (1990). Aesthetic literacy: The psychological context. Journal of Aesthetic Education, 24(1), 135-146.

Patton, M. Q. (2002). Qualitative research \& evaluation methods (3rd ed.). USA: Sage.

Räsänen, M. (2015). Multi-chapter book of visual culture (Visuaalisen kulttuurin monilukukirja). Helsinki: Aalto-yliopiston taiteiden ja suunnittelun korkeakoulu. Aalto-yliopiston julkaisusarja 4/2015.

Serafini, F. (2010). Reading multimodal texts: Perceptual, structural and ideological perspectives. Children's Literature in Education, 41(2), 85-104.

Serafini, F. (2011). Expanding perspectives for comprehending visual images in multimodal texts. Journal of Adolescent \& Adult Literacy, 54(5), 342-350.

Serafini, F. (2012). Reading multimodal texts in the 21st century. Research in the Schools, 19(1), 26-32.

Serafini, F. (2015). Multimodal literacy: From theories to practices. Language Arts, 92(6), 412-422.

Serafini, F., \& Gee, J. P. (2014). Reading the visual: An introduction to teaching multimodal literacy. New York: Teachers Collage Press.

Sinatra, R. (1986). Visual literacy connections to thinking, reading and writing. Springfield Ill.: Thomas.

Schreier, M. (2012). Qualitative content analysis in practice. London: Sage.

Smolkin, L. B., \& Donovan, C. A. (2005). Looking closely at a science trade book: Gail gibbons and multimodal literacy. Language Arts, 83(1), 52-62.

Stafford, T. (2011). Teaching visual literacy in the primary classroom-Comic books, film, television and picture narratives. New York: Routledge.

Tillman, A. (2012). What we see and why it matters: How competency in visual literacy can enhance student learning. (Honors Projects, Paper 9.

Tuomi, J., \& Sarajärvi, A. (2013). Qualitative research and content analysis (Laadullinen tutkimus ja sisällönanalyysi) (10th ed.). Helsinki: Tammi.

Unsworth, L. (2001). Teaching multiliteracies across the curriculum. Chancing contexts of text and image in classroom practice. New York: Open University Press.

Unsworth, L. (2006). Towards a metalanguage for multiliteracies education: Describing the meaning-making resources of language-image interaction. English Teaching: Practice and Critique, 5(1), 55-76.

VUE staff. n.d.a. Summary of the visual thinking strategies grades K-5 curriculum. New York: Vtshome. Retrieved from http://www.vtshome.org/research/articles- other-readings

VUE staff. n.d.b. VTS research and theory. New York: Vtshome. 
Retrieved from http://www.vtshome.org/research/articles-other-readings

Wolfe, P., \& Kleijwegt, D. (2012). Interpreting graphic versions of Shakespearean plays. English Journal, 101(5), 30-36.

Yenawine, P. n.d. (1997). Thoughts on visual literacy. Handbook of research on teaching literacy through the communicative and visual arts in 1997. New York: Vtshome. Retrieved from http://www.vtshome.org/research/visual-thinking

Yenawine, P. (1998). Visual art and student-centered discussions.Theory into Practice, 37(4), 314-321.

Yenawine, P. (1999). Theory into practice: The visual thinking strategies. Presented at the Conference of "Aesthetic and Art Education: A Transdisiplinary Approach”, 1999 Lisbon, Portugal: New York: Vtshome. Retrieved from

http://www.vtshome.org/research/articles-other-readings

Yenawine, P. (2003). Jump starting visual literacy: Thoughts on image selection. Art Education, 56(1), 6-12.

Yenawine, P. (2011). Guidelines for image selection for beginning viewers. New York: Vtshome. Retrieved from http://www.vtshome.org/research/articles-other- readings

Yenawine, P. (2013). Visual thinking strategies: Using art to deepen learning across school disciplines. Cambridge (Mass.): Harvard Education Press. 